\title{
Minimizing environmental impacts of timber products through the production process "From Sawmill to Final Products"
}

\author{
Shankar Adhikari ${ }^{*}$ (ID and Barbara Ozarska²
}

\begin{abstract}
As awareness of climate and environment issues increases and consumption habits change, new opportunities are opening up for the forest industry and wood construction to develop functional green solutions to meet consumers' needs. Wood is a versatile raw material and the only renewable construction material. The manufacture of wood products and structures consumes little energy in comparison to similar products and structures made of other materials. Unlike other materials, most of the energy needed to manufacture wood products is derived from renewable energy sources. The global timber sector currently faces the dual challenges of meeting the growing demand of quality timber products and minimising possible adverse impacts on the environment and human health. Major sources of environmental impacts occur throughout the wood supply chain from sawmills to final products. The major objective of this paper is to explore ways to reduce the environmental impacts of timber products, from sawmills to final products. The specific objectives include the identification of major sources and mechanisms of environmental impacts from timber products, the assessment of the status of energy consumption and GHG emission in wood products during timber processing and manufacturing as well as identifying the potential ways to minimize these environmental impacts.
\end{abstract}

Keywords: Assessment, Environmental impacts, Minimize, Sawmill, Timber products

\section{Background}

Amidst growing environmental consciousness and increasing demand for timber products, the importance of fulfilling growing demand for these products on the one hand, and at the same minimizing environmental impacts, is increasingly recognized. While FAO (2001) had predicted that by the end of 2020, global consumption of industrial timber products will increase by $45 \%$, UK based sustainable real estate organization FIM, based on existing growth levels, has forecasted that global timber consumption in 2020 will be 2.3 billion cubic meters. This is an increase of $24 \%$ from the 2015 level and equivalent to a $4.4 \%$ increase per annum (FIM 2017). Moreover, The World Bank has also forecasted that global timber

\footnotetext{
*Correspondence: adhikarishankar@gmail.com

${ }^{1}$ Department of Forests, Ministry of Forests and Environment,

Kathmandu, Nepal

Full list of author information is available at the end of the article
}

demand is set to quadruple by 2050 (FIM 2017). As a result, there is growing concern about fulfilling the need for increasing demand for timber products without deteriorating the world's forest resources. Hence, enhanced insight is required into ways of improving the efficiency of timber production process, reducing wood wastage and helping the timber sector to address growing environmental challenges (Eshun et al. 2012).

Timber products are regarded as products produced from renewable and sustainable environmental resources (Klein et al. 2016). However, as other products, timber products may create various kinds of environmental impacts at different stages of the timber product supply chain, from harvesting to their disposal (Fig. 1). A major source of the environmental impacts is the consumption of energy required to produce timber products and emission of greenhouse gases (GHG) during the manufacturing process from raw materials to the final products. Although production of timber products also involves 


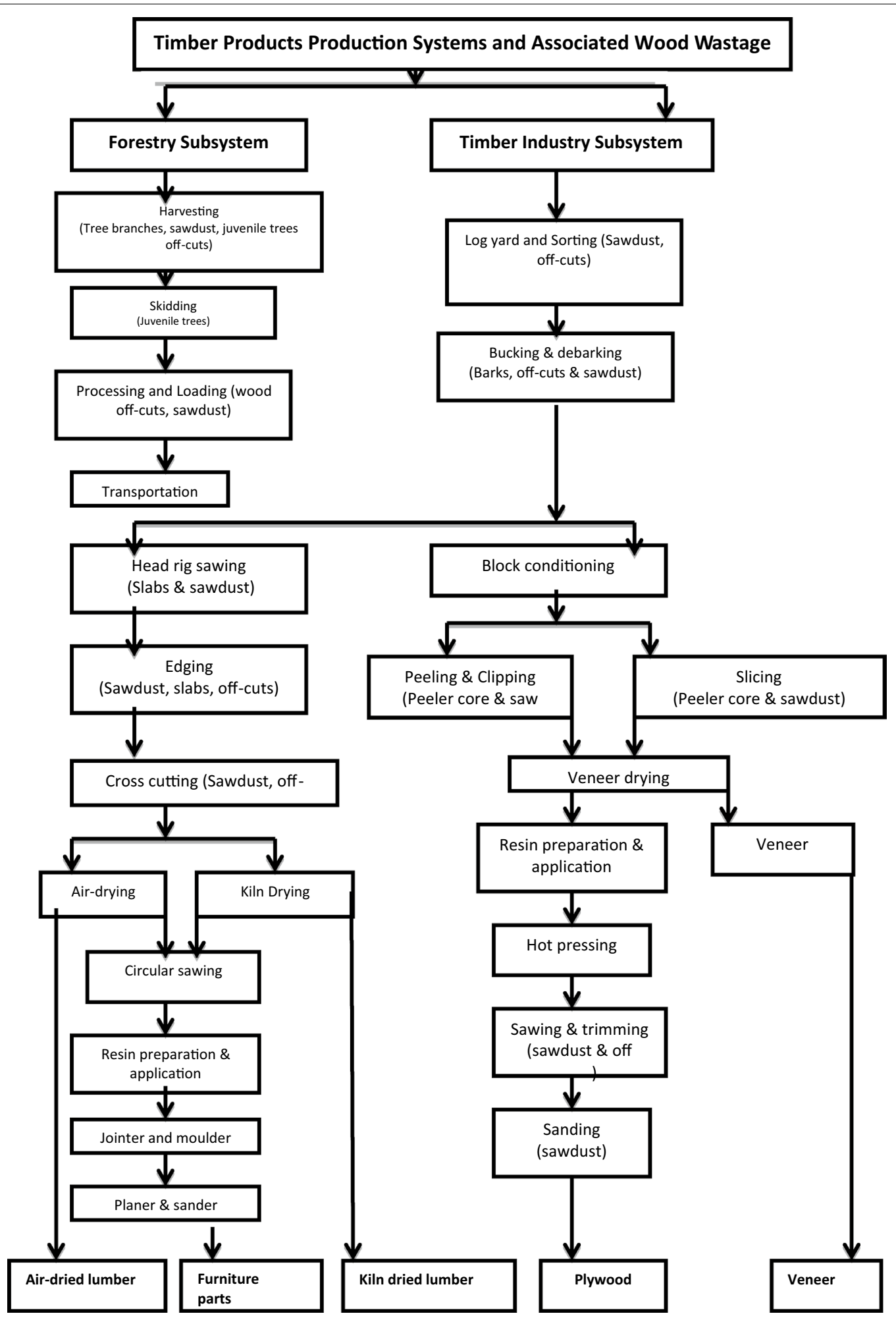

Fig. 1 Flow chart of activities in timber production stages and production of wastage in timber production sector. It represents the typical timber product production system, from harvesting to the final products through two subsystems viz the forestry and timber industry subsystems, within the timber production sector. Modified from Eshun et al. (2012) 
emission of carbon, forest and timber provide carbon sinks because trees consume carbon dioxide from the atmosphere through carbon sequestration (Le Quéré et al. 2009). However, the forestry sector in general, and removal of trees through deforestation contribute to up to $17 \%$ of GHG emission into the atmosphere (Miles and Kapos 2008; Baccini et al. 2012). Other forms of environmental impact associated with timber products are due to the transportation of timber products (Lindholm and Berg 2005), use of chemicals, and wood wastage (Jurgensen et al. 1997; Wootton 2012).

Figure 1 represents the typical timber product production system, from harvesting to the final products. It shows two subsystems, the forestry and timber industry, within the timber production sector.

The major objective of this paper is to explore ways to reduce the environmental impacts of timber products, from sawmills to final products. The specific objectives include the identification of major sources and mechanisms of environmental impacts from timber products, the assessment of the current status of energy consumption and GHG emission in wood products during timber processing as well as identifying the potential ways to minimize these environmental impacts during the timber production process.

Main sources of environmental impacts of timber products can be categorised into physical impacts of timber processing, energy use and production of GHG emissions.

\section{Sources attached to physical impacts of timber products}

The production process for timber products, from log extraction to final products involves several stages, which can affect the surrounding environments in the form of land, air and water pollution. This paper looks into the impacts of timber products from sawmilling to disposal.

\section{Sawmilling}

The sawmilling process involves debarking and cutting of logs into sections, which are sawn into timber boards. Particulate environmental matter arises from log debarking, sawing into boards, wood residues and kiln drying as these processing stages create environmental hazards on the land. Similarly, heavy machinery is involved throughout the process with the impacts on land, water, and air quality. For example, sawmilling sector is the backbone of the wood based industry in Malaysia. A study by Ramasamy et al. (2015) on the environmental impact of sawmilling industry concluded that several gases such as $\mathrm{CO}_{2}, \mathrm{CH}_{4}, \mathrm{NOx}, \mathrm{N}_{2} \mathrm{O}, \mathrm{SO}_{2}$, and $\mathrm{CO}$ were found discharged into the environment and the impacts were found in the form of global warming, acidification, human toxicity, eutrophication, and photo-oxidant formation in Malaysia.

\section{Manufacturing processes}

Timber processing and manufacturing involves different types of machines and processes such as sawing, drying, machining, jointing, gluing and finishing and so on, which can be connected to both environmental hazards, and workers occupational health and safety.

The major hazards with the machines could be classified into mechanical (e.g. crushing, cutting, trapping, shearing, abrasion, friction), structural (e.g. sharp edges, projections, obstructions, potential to fragment, collapse, overturn), physical (e.g. electricity, pressurized content, noise and vibration, heat, moisture or cold temperatures), chemical (e.g. gases, fumes, liquids, dusts, that can cause adverse health effects), ergonomic hazards (awkward working positions, manual handling, repetitive movements), and biological (e.g. present of bacteria, molds in materials used or processed in machinery) (Bluff 2014; Poisson and Chinniah 2016). Furthermore, as workers have to use machinery in all phases of its lifecycle from installation, through operation, maintenance, troubleshooting, repairs, adjustments, set-up, production disruptions, to cleaning and dismantling, they get exposed to various hazards (Poisson and Chinniah 2016; Rus et al. 2008). A study based on sixty-six Australian manufacturing firms which produce and supply machinery into local and international markets found that less than one in ten firms comprehensively recognized hazards, used safe place controls as the primary risk control measures, and provided substantial, good quality information to minimize environmental hazards, but the remaining firms did not consider the environmental impacts (Bluff 2014).

\section{Wood waste and by-products}

Preventing wood waste to improve the efficiency of primary wood utilization significantly helps to reduce the environmental impacts on the one hand, and fulfill timber product demands without further damage to world forest resources on the other. Dionco-Adetayo (2001) has found that out of $1 \mathrm{~m}^{3}$ of tree cut and removed from the forest, about $50 \%$ goes to waste in the form of damaged residuals, followed by abandoned logs (3.75\%), stumps (10\%), tops and branches (33.75\%), and butt trimmings (2.5\%). Wood wastes comprise a significant portion of waste materials. For instance, in Germany, 401 million tonnes of wastes was produced in 2015, out of which waste wood accounts to 11.9 million tonnes. (Sommerhuber et al. 2015; Garcia and Hora 2017). The primary sources of waste wood were wood packaging (21\%), demolition and construction (26.7\%), wood processing industry (14\%), municipal wastes $(20.7 \%)$, imported wood 
(9.7\%) and others such as private households and railway construction (8\%) (Sommerhuber et al. 2015; Garcia and Hora 2017). Similarly, around 1,781,000 tonnes of wood waste was being generated in Australia per annum until 2007 (Taylor and Warnken 2008).

This large amount of wasted wood is often used in the steam production boiler for drying wood products, or is dumped in a site (Eshun et al. 2012). These practices contribute to environmental impacts through wood waste and at the same time lead to depletion of timber resources. Eshun et al. (2012) have identified 19 wood waste sources in Ghana, out of them 3 related to the forestry sub system and 16 to the timber industry subsystem. Major sources of wood waste were low quality logs with large defects, bark, off-cuts, sawdust, slabs, and edged trimmings from sawn timber. There are new technologies for the utilization of low quality logs which can significantly reduce the wood wastage as well as specialized equipment which enables to maximize the wood recovery. However, in many enterprises, particularly in developing countries, these new production methods have not yet been used. Therefore, the major causes of wood wastage can be broadly classified into technologybased factors such as the use of obsolete equipment and inefficient procedures and production methods, management-based operational practices, and administrative and institutional issues.

\section{Toxic chemicals}

Different types of chemicals are used in the process of timber production, especially in preservative treatment, adhesive application and coating of final products. Though these chemicals have played the positive role of increasing the life span of timber products, they can also contribute to environmental impacts through the toxic elements they contain. For example, disposal of timber from demolition building sites still retaining high levels of preservatives is also another important environmental concern. Many countries have introduced policies, which prevent the use of toxic chemicals.

\section{Adhesives}

Even though adhesives are important materials made up of both natural and synthetic substances for bonding wood components into wood product they still might have some negative environmental impacts (Yang and Rosentrater 2015). Phenol-formaldehyde (PF) and ureaformaldehyde (UF) are the two commonly used adhesives in external environments due to high weather- and water-resistance properties (Cetin and Özmen 2002; Pizzi and Mittal 2011; Zhang et al. 2013). However, even the completely cured adhesives regarded as nontoxic and safe, can produce hazardous materials for both humans and the environment (Yang and Rosentrater 2015). For example, some curing agents such as aliphatic amines, and cycloaliphatic amines might cause irritation or damage to the skin, eyes, lungs, and liver (Yang and Rosentrater 2015). Therefore, there is growing interest in the use of adhesives which are environmentally benign (McDevitt and Grigsby 2014).

\section{Wood coatings}

Wood coatings protect wood from environmental influences such as moisture radiation, mechanical and chemical damage, and biological deterioration. However, they contain liquid made up of either organic solvent or water, and have potential to emit volatile organic compounds (VOC). VOC such as those containing chlorofluorocarbon are considered a major environmental problem from both air pollution and human health and safety perspectives (de Meijer 2001).

\section{Impacts associated with transportation}

Environmental impacts associated with the transportation of timber from forest to sawmills, then sawn timber from sawmills to manufacturing companies, and finally to end-users, consume significant amounts of fossil fuel, and thereby emit greenhouse gas (GHG) to the environment. A study carried out in Swedish wood supply chain showed that transportation of timber from forests to industrial sites consumes more fossil fuels than any other part of the chain (Lindholm and Berg 2005). The energy used during the transportation system has impacts on the environment due to release of emission with likely effects on global warming, acidification and eutrophication. For example, organic compounds and phosphorus released to water, and emissions of nitrogenous compounds to both air and water, are the most serious environmental impacts. Similarly, road transport of timber account for almost half of the total GHG emissions. In East Norway, GHG emissions from the final felling, extraction and transport of timber, was found to have $17.893 \mathrm{~kg}$ $\mathrm{CO}_{2}$-equivalents per $\mathrm{m}^{3}$ of timber delivered to industry gate in 2010 (Timmermann and Dibdiakova 2014). As a result, transportation creates impacts on the atmosphere, land and water resources, and noise pollution.

Study by Timmermann and Dibdiakova (2014) assessed annual greenhouse gas effects from seedling, tree felling, transportation and processing of timber products. The study concluded that GHG emissions of forestry supply chain activities and found road transport of timber had the highest impact in climate change category. 


\section{Maintenance of timber products during use}

Maintenance of timber products is carried out either in the form of their full or partial replacement, or by using chemicals to maintain or prolong their life. Therefore, proper care must be taken while maintaining timber products to produce minimum impact on the environment.

\section{Disposal}

Disposal of timber products creates various environmental impacts especially in urban area. Commercial and industrial wastes, construction and demolition activities, pallets and packaging; and utilities are the main sources of urban wood wastes (Taylor and Warnken 2008). When the products are disposed instead of being reused, recycled and refurbished they will create the outside pollution and GHG emissions in many ways due to transport from the source to a landfill site; disposal of synthetic materials contributes to toxic waste, which can leach from landfill, and finally, such materials take up a large amount of space in landfill sites and create the need for new waste disposal sites (ERDC 2001). Although huge volume of waste wood is disposed of to landfill sites in major cities around the world, data on wood waste from the larger categories of waste is not differentiated in most cases. Data on wood waste from Landfills in Sydney and Melbourne, Australia, estimate that approximately 446,000 and 623,000 tonnes are annually disposed of respectively (Taylor et al. 2005). The figure of Melbourne city wood waste disposal is enough to fill the Melbourne Cricket Ground 1.5 time (Taylor et al. 2005).

Similarly, if disposal is carried out by burning of used products, it also produces smokes, contamination and emissions into the environment. For instances, solid contamination has disposal issues by reducing the efficiency of burning and producing waste, whereas excess chlorine in the burning also reduces the burning efficiency and can contribute to the production of dioxins (Taylor et al. 2005).

\section{Sources of impacts due to the use of energy and emission of GHG}

The energy involved in the process and stored in the product is called embodied energy (Ibn-Mohammed et al. 2013). Various types of energy source are used for different stages of timber production. Primarily energy is used for processing and materials handling, drying of raw materials, and associated utilities and services such as boiler steam, and condensation system, heating and lightning of premises (Bergman and Bowe 2008). As a result, there would be two phenomena involved together, energy consumption during the production process, and emission of greenhouse gas and other gasses as a consequence.

\section{Sources of energy}

The major sources of energy in sawmilling are either electrical energy or thermal energy. Electrical energy includes electricity supplied through the grid system, and is primarily used in sawing process, whereas thermal or heat energy is generated through biomass and used primarily for drying of sawn timber. Energy sources can also be classified based on the origin of the energy (Bergman and Bowe 2008). For example, if the energy is produced within the sawmill site, and used for drying or other purposes, it is called an onsite energy source. On the other hand, if energy requirements are fulfilled from outside of the sawmill site, they are referred as offsite energy sources.

On the other hand, sources of energy can also be classified based on the sources of carbon emission as the part of sawmilling procedures. For example, the energy produced as a result of the burning of wood biomass is called a biogenic energy, whereas energy derived from fossil fuel is called as the anthropogenic emission source (Gunn et al. 2012).

Sources of energy from fossil fuel have a significant impact on the environment and are non-renewable. If the sources of energy are renewable and have less impact on the environment such as hydroelectricity, wind energy, are known as renewable sources of energy. These have a lower environmental impacts and health hazards.

\section{GHG emission of timber products}

The energy sources and the ways they are used contribute to the production of GHG emissions and other environmental impacts.

Major environmental impacts associated with timber products include emission to air especially emission of GHG among others (Wilnhammer et al. 2015; Van et al. 2017). This kind of impact is called as carbon foot printing or the carbon impact of timber products (Box 1). 


\section{Box 1: The wood product carbon impact equation}

$A-B-C-D=E$

A. Manufacturing carbon: Manufacturing uses energy and most energy production results in carbon dioxide release.

B. Bio-fuel: Wood residues are often burned for energy during the manufacture of wood products.

C. Carbon storage: Carbon dioxide is absorbed from the atmosphere during photosynthesis by the growing tree. This carbon is converted to wood, bark and other parts of the tree.

D. Substitution: There are alternatives to wood products for most applications. However, almost all of these non-wood alternatives require more energy for their manufacture, and the energy used is almost entirely fossil carbon.

E. Total Carbon Footprint or Carbon Credit: The bio-fuel (B), carbon storage (C) and substitution (D) effects reduce the carbon footprint of wood products. In fact, these effects together are almost always greater than the manufacturing carbon (A), so the overall carbon effect of using wood products is a negative carbon footprint (i.e. carbon credit or storage). Thus using wood products can help us to reduce contributions to climate change and conserve energy resources.

Source: Bergman et al. (2014)

The forest industry especially the timber production process contributes to global GHG emission in different ways from harvesting to end use and disposal. Manufacturing-related emissions dominate the GHG contribution from the sector by accounting for $55 \%$ of all emissions occurring throughout the value chain (Miner 2010) which is approximately, 490 million tonnes of $\mathrm{CO}_{2}$ equivalent per year. This is mainly due to the fuel combustion at the manufacturing facilities. Similarly, a significant amount of emission of about 238 million tonnes, also occurs at the end of the life cycle, especially from methane emission (235 million tonnes) and emission associated with the burning of used products (3 million tonnes) (Miner 2010).

A study on life cycle impacts and benefits of wood along the value chain in Switzerland shows that high environmental benefits in construction and furniture are often achieved when replacing conventional heat production and energy-consuming materials. For instance, replacement of fossil fuels for energy or energy-intensive building materials, and taking appropriate measures to minimize negative effects such as particulate matter emissions could ensure high environmental benefits (Suter et al. 2017).

\section{Methods of impact assessment}

Major methods in vogue for the impact assessment of environmental sectors are life cycle assessment (LCA) (Gustavsson and Sathre 2006; Ramesh et al. 2010; Roy et al. 2009), input-output methods (Ivanova and Rolfe 2011), cost-benefit analysis (Atkinson and Mourato 2006), health hazard scoring (HHS) system, material input per service-unit (MIPS), Swiss eco-point (SEP) method, sustainable process index (SPl), Society of Environmental Toxicology and Chemistry's life-cycle impact assessment (SETAC LCA), and environmental priority system (EPS) (Hertwich et al. 1997).

Though most of these methods could be applied to examine the complex interaction among the timber production process from the sawmill to final product, and their impact on their corresponding environments, LCA can explain such a relationship in a more comprehensive way. This is because it is a procedure for evaluating the energy and environmental burdens related to a process or activity, which is carried out with the help of identifying the source of energy used or consumption, the materials used and their impact on the environment (Goedkoop et al. 2008).

So far, extensive studies on LCA and various aspect of timber production are well documented (Cabeza et al. 2014; Dodoo et al. 2014a, 2014b; Lippke et al. 2004; Mirabella et al. 2014; Puettmann and Wilson 2007). Among them, the Consortium for Research on Renewable Industrial Materials (CORRIM), has published a 22-module research plan and protocol to develop a LCA for residential structures and other wood uses while evaluating the life cycle inventory (LCI) databases for use in each stage of processing "from cradle to grave" (Lippke et al. 2004; NCASI 2006).

\section{Benefits of using timber in various products}

Wood competes with many other materials in various products and applications. The main competitors are: steel, concrete, aluminum, brick and plastic (Taylor 2003; George 2008). Many studies have been conducted which compared the environmental impacts of wood and its competing materials. Production of wood results in few greenhouse gas emissions, in which the main emission source is the energy used in wood processing. The energy saving requirements of the industry in wood processing can be met with the use of wood residue, which provides more energy savings compared to the use of fossil fuel based energy. On the other hand, production of most competitor materials results in high greenhouse 
Table 1 Greenhouse gas emission profile of wood and key competitors. Adopted from George (2008)

\begin{tabular}{lll}
\hline Materials & $\begin{array}{l}\text { Greenhouse } \\
\text { gas emissions } \\
\text { per tonne } \\
\text { material } \\
\text { (tCO }\end{array}$ & Sources \\
& 22.4 & Norgate et al. (2007); George (2008) \\
\hline $\begin{array}{c}\text { Aluminum } \\
\text { Steel (blast furnace } \\
\text { production) }\end{array}$ & 2.55 & George (2008) \\
$\begin{array}{c}\text { Steel (scrap-based } \\
\text { electronic arc fur- } \\
\text { nace production) }\end{array}$ & 1.1 & George (2008) \\
$\begin{array}{c}\text { Cement } \\
\text { Hardwood (rough } \\
\text { sawn kiln dried) }\end{array}$ & 0.23 & George (2008) \\
$\begin{array}{c}\text { Softwood (rough } \\
\text { sawn kiln dried) }\end{array}$ & 0.234 & George (2008) \\
$\begin{array}{c}\text { Medium density } \\
\text { fibreboard (MDF) }\end{array}$ & 0.726 & George (2008) \\
\begin{tabular}{c} 
Particle board \\
\hline
\end{tabular} & 0.982 & George (2008) \\
\hline
\end{tabular}

emissions. The emission values of wood and competitor products are presented in Table 1.

Wood consumes less energy, and emits less pollutant to the environment, thereby adds environmental values throughout the life of the structure. In contrast, steel and concrete use more energy, emit more greenhouse gases, and release more air and water pollutants during the manufacturing process than that of wood products (APA 2017). For example, wood is 105 times more efficient than concrete, and 400 times more efficient than steel. When it comes to energy consumption, steel and concrete consumes 12 and $20 \%$ more than wood products respectively. Similarly, steel emits 15\% more GHG than wood and concrete emits 29\% GHG more than wood. Likewise, steel and concrete significantly contribute in water pollution than that of wood products. For example, steel pollutes $300 \%$ more water resources, and concrete pollutes $225 \%$ more water than the wood products (APA 2017).

Unlike their competitors, wood products are part of the carbon cycle. Therefore, as tree absorb carbon dioxide and act as an important carbon sink, they contribute to carbon sequestration and climate change mitigation as well (George 2008). There are no environmentally perfect building and construction materials; however, wood is still an intelligent and informed choice especially for many commercial and residential buildings (APA 2017) mainly due to low energy use and $\mathrm{CO}_{2}$ emission than that of steel and concrete products. For example, wood-based building construction consumes 3800 gigajouls (GJ) of total energy whereas steel and concrete based structure consumes 7350 and 5500 GJ energy, respectively.
Similarly, on carbon emission, wood-based construction emits $73000 \mathrm{~kg}$ carbon emission whereas steel and concrete based construction emits 105,000 and 132,000 kg carbon, respectively (APA 2017).

Most construction materials such as steel, concrete, aluminum and plastic require a high energy input during the manufacturing process while the manufacture of timber products uses much less energy than the competitive materials. (Figure 2).

Many studies have also confirmed that timber products have a net carbon storage value which means that they store more carbon than is required in their manufacture. Typical results for various materials are shown in Table 2 .

\section{Possible ways to reduce the environmental impacts of timber products}

With the identification of potential sources of environmental impact and their mechanisms at different stages of the timber production process, the following methods can be applied to tackle the associated contemporary challenges.

\section{Changes in energy sources and consumption pattern}

As energy sources and consumption patterns are critical towards overall environmental impacts of energy consumption practices, environmentally friendly energy sources should be promoted. For example, fossil fuel based energy such as energy generated from coal, has more adverse environmental impacts than that of nonfossil based energy sources. Similarly, anthropogenic emissions due to fossil fuel have comparatively higher emission and negative environmental impacts, than that of biogenic emission from burning wood materials (Bergman and Bowe 2008). Therefore, while choosing energy sources for the timber production process, there needs to be proper care in the use of renewable energy instead of fossil fuel-based energy techniques. Even if fossil fuel based energy source are to be used, efforts must be made to use as little energy as possible.

\section{Use of Sawmill by-products as a thermal energy}

Instead of leaving the sawmill products within the premises of sawmills, and creating environmental hazards, they could be collected and used for producing thermal energy to reduce environmental impacts. This would help to minimize the reliance on offsite fossils fuel to some extent and promotes the production of bioenergy at the sawmill site. For example, the sawdust could be recycled into a bio-briquette. Such bio-briquettes have even higher heating value ranged from 14.88 up to $16.94 \mathrm{MJ} /$ $\mathrm{kg}$, than that of the briquette made from other substances (Lela et al. 2016). 
Greenhouse gases emitted in the manufacture of building materials used in a range of construction components for a single storey house in Sydney, Australia

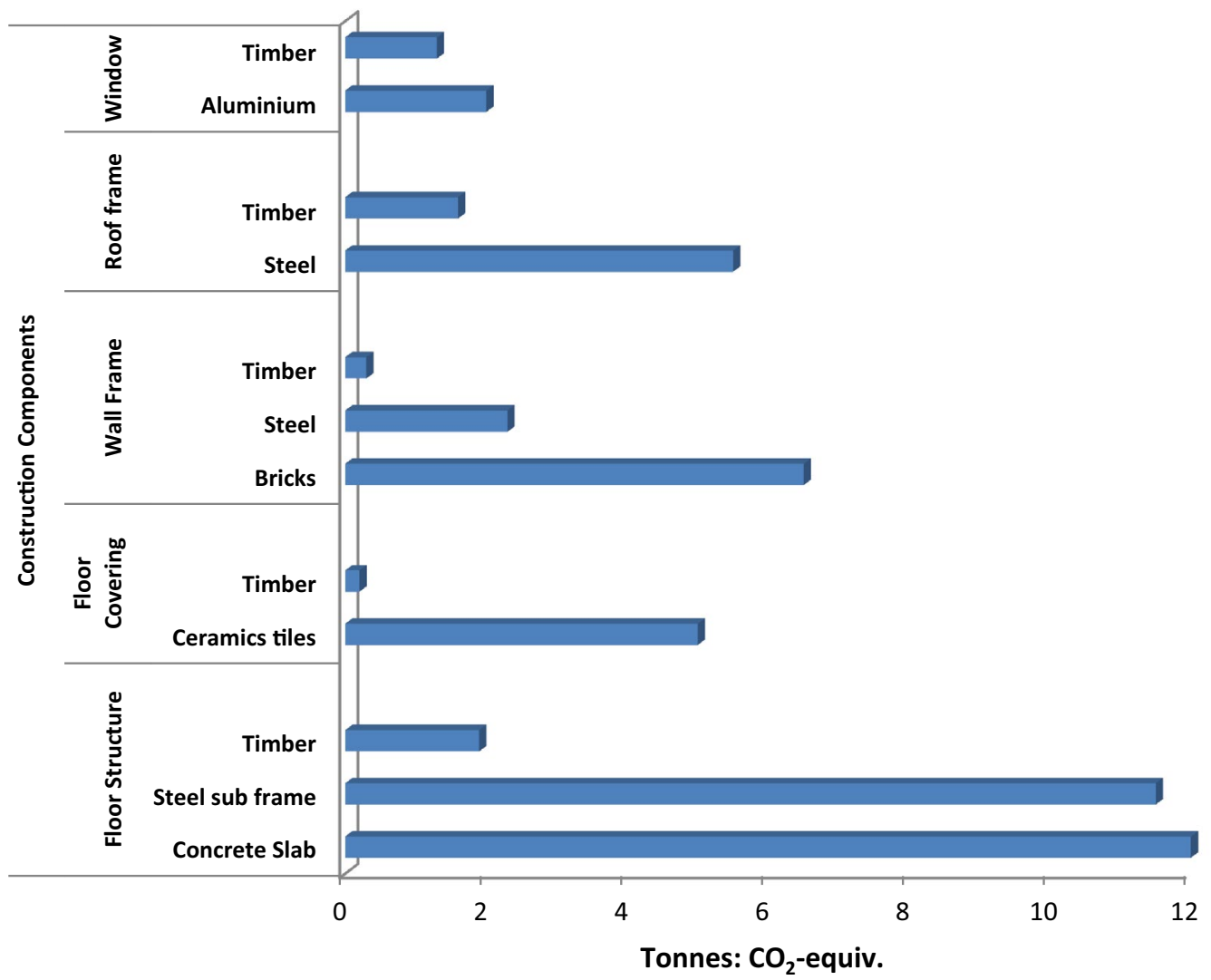

Fig. 2 Greenhouse gases emitted in the manufacture of building materials used in a range of construction components for a single storey house in Sydney, Australia. Modified from Australian Government, Forest and Wood Products Research and Development Corporation (2006)

Table 2 Carbon released in the manufacture of building materials compared with carbon stored in material. Adopted from Williamson et al. (2001)

\begin{tabular}{lcrrr}
\hline Material & Sawn timber & Steel & Concrete & Aluminum \\
\hline Carbon released $\left(\mathrm{kg} / \mathrm{m}^{3}\right)$ & 15 & 5320 & 120 & 22,000 \\
Carbon stored $\left(\mathrm{kg} / \mathrm{m}^{3}\right)$ & 250 & 0 & 0 & 0 \\
\hline
\end{tabular}

\section{Improved sawmilling and sawing machinery}

Improved sawmilling techniques, machinery and manufactured products help reducing the environmental hazards and human health problems (Harms-Ringdahl et al. 2000) and ultimately contribute to environmental sustainability in numerous ways (Gaussin et al. 2013). The use of recent technology and safety procedures could be helpful in these regards.

Laurent et al. (2016) conducted environmental assessment of a wood manufacturing industry and established environmental profile of the company so that company continue to maintain its environmental integrity as well as environmental profile of different wood products it manufactures.

First, improved and new varieties of machinery instead of old and obsolete one help reducing the wood waste, thereby reduce environmental impacts, while increasing the working efficiency in terms of time, energy and efforts. Second, hazardous energies related to machinery use can be minimised as safety and precautionary measures such as lockout system. The lockout measures is a step-by-step procedure, carried out by authorised employee to prevent inadvertent machine energization or the release of stored energy, which is in practice in Canada and the United States (Poisson and Chinniah 2016). Third, and most importantly, workers health and safety, and ergonomic measures have to be taken into account while planning and executing the sawmilling operation in the field (Jones and Kumar 2007, 2010). 


\section{Improved energy efficiency in drying system}

Wood drying is the key to controlling wood quality of final products, and it consumes up to $90 \%$ of the processing time in hardwoods and more than $70 \%$ of primary processing cost, with the use of significant amounts of heat and energy (Goreshnev et al. 2013). The supplied heat is primarily used for the drying process, which is carried out in a drying kiln. Lead-time and wood quality are the major priority before energy consumption while producing the lumber (Anderson and Westerlund 2014). Therefore, the introduction of improved drying processes including simple yet environmentally friendly drying process would be beneficial to reduce the environmental impacts while ensuring the quality of final products. For example, solar drying provides opportunity as an alternative method of drying timber, while using renewable solar energy to address the shortcomings associated with fossil fuel based drying process. In addition, solar systems use the energy from sun, which is abundant, inexhaustible and nonpolluting (Akinola 1999; Akinola et al. 2006; Kumar and Kishankumar 2016), thereby has little environmental impact (Belessiotis and Delyannis 2011), unlike other forms of fossil fuel based drying methods. However, external factors such as air temperature, air velocity geographic locations, and relative humidity influence the potential drying rate. Yet, it has advantages over open-to-the-sun or air drying techniques, because the solar dryer traps solar energy to increase the temperature of circulating air and ensures the required equilibrium moisture content (EMC), enhanced shelf life, value addition, and quality enhancement (Helwa et al. 2004; LayThong 1999). These features can be further complemented by the controlled air humidity and other drying conditions, even with the use of water sprayers in some cases. However, there might still be chances that productivity is affected by weather condition such as rainfall, cloud cover, and less predictable outcomes than that of industrial kilns (Haque and Langrish 2005).

Solar kiln drying is usually affected by geographic and climatic conditions. For example, the temperature inside the kiln is affected by the ambient temperature and solar radiation (Hasan and Langrish 2014; Phonetip et al. 2017a). Areas with low humidity offer a productivity performance for solar kilns (Ong 1997). According to Phonetip et al. (2017b), decreasing the relative humidity (RH) level to $40 \%$ can dry boards faster than when the conditions are maintained at $60 \% \mathrm{RH}$. Taking advantage of a low ambient RH could result in several benefits, such as lowering the consumption of water and energy.

A study by Phonetip et al. (2018) described a method that used the combined tools of GIS and Fuzzy theory to identify the most suitable locations for solar kilns based on variables of geographical and climatic conditions and restricted areas, using an example location in Vientiane, Laos. This method can be applied to different geographical regions and local climatic seasons.

Therefore, in order to improve efficiency and reduce the environmental impacts, various kind of solar drying are in practice, such as integral, distributed and mixed type solar dryers based on the mode of utilization of solar heat, and greenhouse system, external collector, and mixed mode solar drying depending on greenhouse systems. Currently, enhanced solar timber kilns can also be used with characteristic features of solar energy storage with independent heating, integration of an air heater in the storage and in the drying chamber, and management of different drying cycles based on the quality control of the products (Ugwu et al. 2015).

Overall, solar drying has more environmental advantages due to shorter drying time, and better drying quality than that of air-drying. Similarly, it requires, low operating costs and lower training manpower, along with the chances of having EMC in broad range of climates, and ultimately constitutes an environmentally friendly technique due to its reliance on renewable resources and low environmental impact.

Studies on improving energy efficiencies have shown that if available state-of-the-art technologies are applied in drying kilns, it could reduce the heat consumption by about 60\% (Anderson and Westerlund 2011, 2014; Johansson and Westerlund 2000). Moreover, a study by Anderson and Westerlund (2014) using the Torksim simulation program has further reported that energy recovery technologies in the sawmill industry could save considerable amounts of energy and biomass for the other purpose. According to the authors, use of a heat exchanger, mechanical heat pump, and open absorption system are the major energy recovery technologies. For instance, open absorption system is the most effective which will reduce energy consumption by $67.5 \%$, whereas mechanical heat pump could also decrease a significant amount of energy usage and result in a large heat surplus in the drying system. However, the latter requires high consumption of electricity. In contrast, use of heat exchanger technology contributes only a marginal increase in energy efficiency of $4-10 \%$ depending upon the sawmill condition and drying scheme. Therefore, findings of such studies mainly related to the result of higher energy efficiency from open absorption system should be promoted to reduce the energy use and GHG emission, increase the efficiency, and minimize the environmental impacts. 


\section{Use of environmentally friendly chemicals Preservatives}

There is a growing trend towards environmentally friendly preservatives to reduce the environmental impacts while improving the durability of timber products. In this context, environmentally benign wood preservative systems can be developed with proper combination of an organic biocide with metal chelating and/ or antioxidant additives (Schultz and Nicholas 2002). That will not only enhance protection of wood against fungi as compared to the biocide alone, but also consequently, help reduce the environmental impacts especially on land and water resources. Physical barriers have been accepted as alternative non-biocidal wood protection method in India as they reduce leaching and subsequent negative impacts of wood preservative components to the organisms in vicinity (Sreeja and Edwin 2013).

Policy and legislative measures to ban the use of toxic preservatives, and growing awareness on using less toxic and more environmentally friendly preservatives would be another way to reduce the environmental impacts (Lin et al. 2009). For example, a number of toxic preservatives such as CCA, cresote, and preservatives based on volatile organic solvent (VOC), are restricted in Europe and the USA. Instead, use of environmentally friendly preservatives such as copper-organic preservatives replacing $\mathrm{CCA}, \mathrm{CCB}$ and $\mathrm{CCP}$ preservatives, microemulsion water-dilutable concentrates with organic fungicides and insecticides, and water and solvent-based coloured preservatives replacing creosote, have emerged to fill the gap (Coggins 2008; EU 2006). Therefore, stringent environmental policies will have to be practiced to reduce the use of harmful chemicals in wood preservatives, as practiced under Biocidal Products Directives within European Union (Hingston et al. 2001) and restricted pesticidal use of three primary heavy duty wood preservatives ("HDWPs") under Environmental Protection Agency, USA in 2008 (Tomasovic 2012).

Australian Government Department of Agriculture and Water Resources (2016) accepts certain permanent preservative treatments as biosecurity treatments for use on certain timber products and timber packaging. For a timber preservative treatment to sufficiently address biosecurity risks and be accepted as a biosecurity treatment by the department, it must meet the following requirements:

suitable treatment application methods, preservative penetration zone requirements, preservative retention requirements and accepted preservative formulations.

\section{Adhesives}

As biochemical adhesives have 22\% fewer environmental impacts than that of petrochemical adhesives (Yang and
Rosentrater 2015), use of biochemical adhesives should be encouraged. For example, Pizzi (2006) have identified bio-based adhesives such as tannin, protein, carbohydrate, lignin, and unsaturated oil to maintain both environmentally friendly alternatives and efficient traditional adhesives of the timber industries. Consistent with these findings, Navarrete et al. (2012) conducted a comparative study between the emission from particle board produced with UF and the natural adhesives and found that there was at least seven times higher emission of urea formaldehyde than that of biochemical based adhesive such as lignin and tannin. Yet, the impacts from these biochemical adhesive is quite significant, therefore various innovative measures have to be taken to reduce the impacts on the environment. For example, adhesive based on hexamine could be used to reduce the impact of formaldehyde. Similarly, environmentally-friendly products such as tannin-hexamine adhesive, and in case of lignin adhesive, adhesives pressed at high speed, in the presence of pre-methylated lignin could be used to reduce the environmental impacts (Yang and Rosentrater 2015). Furthermore, soy-based adhesive has also been effective in increasing the wet bond strength with the use of polyamidoamine-epichlorohydrin (PAE) resin as a coreactant. That has led to resurgence in soy-based adhesive consumption with minimal environmental impacts (Frihart and Birkeland 2014).

In India, extensive research studies have been carried out since 1980 on extending the soya flour to synthetic resin (Sarkar et al. 1985; Zoolagud et al. 1997). Mamatha et al. (2011) developed phenol-soya adhesive for the manufacture of exterior grade plywood. About $40 \%$ substitution of phenol by soya was optimized for making exterior grade plywood having strength properties confirming to relevant standard requirements. The substitution not only helps to minimize the formaldehyde release from the products and disposal of waster for better utilization, but also reduces the air and water pollution along with minimization of production cost of the plywood products due to reduced cost in resin system (Mamatha et al. 2011).

A recently published book "Bio-based Wood Adhesives" by Zhongqi He (2017) provides the synthesis of the fundamental knowledge and latest research on bio-based adhesives from a remarkable range of natural products and byproducts, and identifies need areas and provides directions of future bio-based adhesive research.

Policy measures should be placed on restriction of VOCs to the atmosphere. Likewise, an interesting shift from using less environmentally harmful adhesive in joining wood components for furniture and interior joinery by wood welding technology without the use of adhesive has been also initiated. This could be explained 
by the polymerization and cross-linking of lignin and of carbohydrate-derived furfural (Gfeller et al. 2003). Many studies have been conducted on wood welding using high speed rotation welding (Pizzi et al. 2004; Belleville et al. 2016) and linear welding (Mansouri et al. 2010; Martins et al. 2013; Belleville et al. 2017). If this technique could be scaled up successfully, it would contribute to reduce the adhesive based emission and environmental hazard involved in the timber productions process.

While choosing the adhesive during the course of timber product manufacturing and production processes, proper attention has to be given to environmentally friendly either bio-based adhesive or techniques without using adhesive as far as possible to reduce the impact both on the environment, and the human health.

\section{Wood coating}

Over the past few years, regulation under the Clean Air Act (USA) and consumer demand for low-VOC finishes have led to the creation of a variety of new products. Many penetrating finishes, such as semi-transparent stains, have low solids content (pigment, oils, polymers) and are being reformulated to meet low-VOC regulations. To meet the VOC requirements, these reformulated finishes may contain higher solids content, reactive diluents (dilutants or thinners), new types of solvents and/or co-solvents, or other non-traditional substitutes. These low-VOC requirements favour film-forming formulations over products that penetrate the wood surface, since traditional wood stains were formulated to penetrate the wood, and the new formulations that meet the VOC requirements may not penetrate as well.

Another way to decrease air emissions from wood finishes is to change the formulation to a water-based coating. The new water-based products achieve a dramatic improvement over solvent-based finishes in terms of VOC emissions and human comfort and health. Companies that have successfully switched to water-based coatings have worked closely with their suppliers to determine the best water-based formula for their specific uses.

\section{Wood waste management}

Eshun et al. (2012) and EPA (2015) have listed ways to minimize wood waste and wood waste management. Main measures to wood waste management include, among others, good operating practices, technology changes, changes in input materials, waste recycling, and waste reuse/recover practices. Similarly, EPA (2015) has described the waste reduction opportunities via lumber receiving, drying and storage; rough end and gluing; machining and sanding; assembly; finishing; packing, shipping and warehouse; building and equipment maintenance.

It is interesting to note that developed countries such as Australia and Sweden place more emphasis on waste recycling, and waste reuse/recover, whereas other countries such as Taiwan, South Africa, and India have put emphasis on improving almost all processing and manufacturing techniques identified above. This might be due to the fact that developed countries may already have good operating practices and required technology in the timber production sector. A study carried out by Daian and Ozarska (2009) in Australia has highlighted the need for using recovered and waste wood in the mulching and compost sector, bioenergy sector, animal product sector, and engineered wood product sector.

During 2013 and 2014, Italy re-used 95\% of the waste wood to produce particleboard, while Germany and United Kingdom shared the account to 34 and 53\% respectively (Garcia and Hora 2017).

In Europe, the Waste Framework Directive (2008/98/ EC) provides a guideline of basic concepts and procedure related to the waste management. A concept called "end-of-waste criteria" has been introduced that is used as a guideline to determine when a waste ceases to be a waste and becomes a secondary raw material. In this concept, waste hierarchy is maintained from landfill through recovery, recycling, reuse to reduce from the least favoured to most favoured option (Garcia and Hora 2017). The values and ways to wood recovery and recycling, classified into direct and indirect recycling, have been well illustrated by Taylor and Warnken 2008 (Fig. 3). Indirect recycling of wood products results in compost or mulch which will decompose into carbon dioxide aerobically. Similarly, direct recycling and reuse of recovered wood into timber products prolong the service life of the timber and at the same time provides the opportunity of potential recovery at end-of-life. Degradable organic carbon contained in the wood disseminate into methane in the landfill site. Methane has 25 times higher global warming potential, so recovering wood will prevent the greenhouse gases (Taylor and Warnken 2008).

\section{Integrated industrial sites}

With due consideration of growing energy demand from the different industrial sectors, an essential strategy would be the development of highly integrated industrial sites. Such sites would serve to lower energy and resource consumption and, at the same time, complement one plant to another. For example, saw mills would supply huge biomass to other pellet plants, pulp and paper plant, and combined heat and power (CHP) plants, and some portion of such biomass would be used to fulfill the internal heat requirements as well (Anderson and Toffolo 


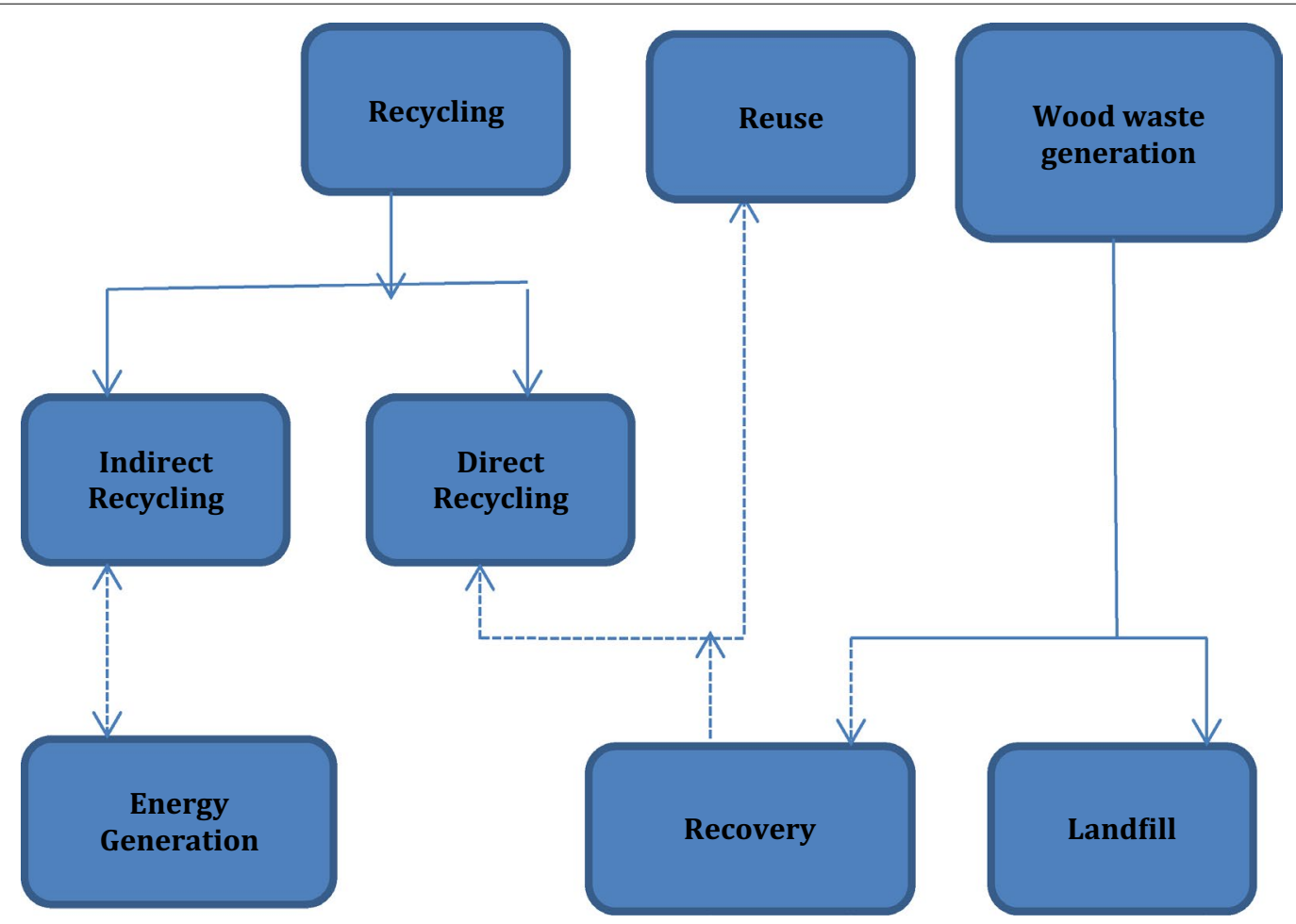

Fig. 3 Schematic flow of recycling, reuse and recovery of wood products. Modified from Taylor and Warnken (2008)

2013). Therefore, if these plants were combined it would reduce the energy and resource consumption and help reduce the environmental impacts.

\section{Energy efficient biofuel and improved transportation system}

Environmental impacts associated with transportation could be minimized by changing the source of energy and mode of transportation of the timber products. Use of renewable sources of energy such as electricity generated from hydropower, and biofuel, instead of fossil based energy would reduce emission during the transportation. Interestingly, in Sweden it was reported that transporting forest products via railway transport requires less process energy than by using road vehicles. Furthermore, use of biofuel instead of fossil fuel in a lorry could replace about 96\% of fossil energy (Lindholm and Berg 2005).

By- or co-product or even wood waste can be a feedstock for second generation biofuel (Cantrell et al. 2008; Havlík et al. 2011; Sklar 2008), or be supplied by dedicated plantations. The latter ones seems more promising and can be established on marginal lands (Tilman et al. 2006; Zomer et al. 2008, Havlík et al. 2011), or enter into direct competition with conventional agricultural production (Field et al. 2008; Gurgel et al. 2007) and other services. Therefore, improved transportation system for timber products with the use of energy efficient biofuel should be promoted.

\section{Safe disposal}

Environmental impacts related to disposal of wood wastage can be minimized by using a minimum amount of materials required for the production process, and renewable materials, and by avoiding materials that deplete natural resources while prompting recycle and recyclable material and waste by-products. Similarly, those left for disposal should be put into safe disposal landfill sites. Landfill sites represent a major disposal option for wood wastes in many countries. For example, in Australia, it is estimated that approximately 2.3 million tonnes of solid wood products are placed in all Australian landfills each year (Ximenes et al. 2008). There should be reliable landfill side for safe disposal of wood wastage.

\section{Policy support}

Overarching policy and institutional support should be in place in order to realize the improvements with regard to minimizing adverse environmental impacts as a result of the production process of timber products in general and sawmilling in particular. Similarly, it should encourage robust production planning (Zanjani et al. 2010), suitable policy measure of impacts minimization and quality 
enhancement (Loxton et al. 2013), and further collaboration with other stakeholders.

\section{Others}

Apart from aforementioned measures to minimize environmental impact as a result of timber production process, some other social, ecological and economic factors should also be taken into account. For example, in order to obtain sustained supply for raw timber from the forest, the timbers supplied from sustainably managed and certified forest is being encouraged (Päivinen et al. 2012). In addition, timber industry should incentivize and support the endeavors of both government and private sectors on plantation and management of forests, so that it would create harmony among them and help the regular supply of raw materials to the industry. Similarly, societal need, interest, and capacity should also be considered while designing, and operating the sawmill industry. Further, proper coordination and collaboration among different stakeholders are also crucial for the success of the industry.

\section{Conclusion}

Major sources of environmental impacts occur throughout the wood supply chain from sawmills to final products. Many studies have been conducted with the aim to identify environmental impacts of timber products. The studies, in particular the ones based on LCA methods have provided comprehensive coverage of different processes such as energy consumption, manufacturing process and their impacts on the environments. The impacts can be minimized in various ways: changes in energy consumption behavior, promotion of renewable energy, improved sawing and sawmilling practices, proper wood waste management, use of less toxic chemicals on the treatment of wood and timber products, and most importantly use of energy efficient and environment friendly drying techniques and energy sources such as effective air drying, improved solar and kiln drying, microwave modification and vacuum technology inter alia. Moreover, there needs to be proper policy support to promote the concept of integrated industrial site with effective coordination and collaboration among relevant stakeholders. That collaborative work not only helps produce quality forest products, but also reduces their concomitant environmental impacts. Moreover, it should help to ensure the broad goal of environmental sustainability, while recognizing the timber sector as a part of an integrated approach of sustainable development.

\section{Authors' contributions}

SA drafted the manuscript. BO provided conceptual guidance and polished and revised the manuscript. Both authors read and approved the final manuscript.

\section{Author details}

${ }^{1}$ Department of Forests, Ministry of Forests and Environment, Kathmandu, Nepal. ${ }^{2}$ School of Ecosystem and Forests Science, University of Melbourne, Burnley Campus, Melbourne, Australia.

\section{Competing interests}

The authors declare that they have no competing interests.

\section{Consent for publication}

The authors read the manuscript and agree for publication.

Ethics approval and consent to participate

The authors declare that this manuscript is not published or consider for publication elsewhere.

\section{Funding}

Not applicable.

\section{Publisher's Note}

Springer Nature remains neutral with regard to jurisdictional claims in published maps and institutional affiliations.

Received: 6 November 2017 Accepted: 2 April 2018

Published online: 20 April 2018

\section{References}

Akinola AO (1999) Development and performance evaluation of a mixedmode solar food dryer. Federal University of Technology, Akure

Akinola O, Akinyemi A, Bolaji B (2006) Evaluation of traditional and solar fish drying systems towards enhancing fish storage and preservation in nigeria: Abeokuta local governments as case study. J Fisheries Int 1:44-49

Anderson J-O, Toffolo A (2013) Improving energy efficiency of sawmil industrial sites by integration with pellet and CHP plants. Appl Energy 111:791-800

Anderson J-O, Westerlund L (2011) Surplus biomass through energy efficient kilns. Appl Energy 88:4848-4853

Anderson J-O, Westerlund L (2014) Improved energy efficiency in sawmill drying system. Appl Energy 113:891-901

APA (2017) Sustainable building, sustainable future. APA, Washington D.C

Atkinson G, Mourato S (2006) Cost-benefit analysis and the environment: recent developments. Organisation for economic co-operation and development. OECD, Paris. ISBN 9264010041

Australian Government, Department of Agriculture and Water Resources 2016. Timber permanent preservative treatment requirements. http://www. agriculture.gov.au/import/goods/timber/approved-treatments-timber/ permanent-preservative-treatment. Accessed 19 Mar 2018

Australian Government, Forest and Wood Products Research and Development Corporation (2006) Forest, wood and Australia's carbon balance. Australian Government, Forest and Wood Products Research and Development Corporation, Australia

Baccini AGSJ, Goetz SJ, Walker WS, Laporte NT, Sun M, Sulla-Menashe D, Hackler J, Beck PSA, Dubayah R, Friedl MA, Samanta S (2012) Estimated carbon dioxide emissions from tropical deforestation improved by carbon-density maps. Nat Climate Change 2:182

Belessiotis V, Delyannis E (2011) Solar drying. Sol Energy 85:1665-1691

Belleville B, Pizzi A, Ozarska B (2016) Assessing the potential of wood welding for Australian eucalypts and exotic species. Eur J Wood and Wood Prod 74:753-757

Belleville B, Amirou S, PIzzi A, Ozarska B (2017) Optimization of wood welding parameters for Australian hardwood species. BioResources 12:1007-1014

Bergman RD, Bowe SA (2008) Environmental impact of producing hardwood lumber using life-cycle inventory. Wood Fiber Sci 40:448-458

Bergman R, Puettmann M, Taylor A, Skog KE (2014) The carbon impacts of wood products. For Products J 64:220-231 
Bluff E (2014) Safety in machinery design and construction: performance for substantive safety outcomes. Saf Sci 66:27-35

Cabeza LF, Rincón L, Vilariño V, Pérez G, Castell A (2014) Life cycle assessment (LCA) and life cycle energy analysis (LCEA) of buildings and the building sector: a review. Renew Sustain Energy Rev 29:394-416

Cantrell KB, Ducey T, Ro KS, Hunt PG (2008) Livestock waste-to-bioenergy generation opportunities. Biores Technol 99:7941-7953

Cetin NS, Özmen N (2002) Use of organosolv lignin in phenol-formaldehyde resins for particleboard production: I. Organosolv lignin modified resins. Int J Adhes Adhes 22:477-480

Coggins C (2008) Trends in timber preservation—a global perspective. J Tropical For Sci 20:264-272

Daian G, Ozarska B (2009) Wood waste management practices and strategies to increase sustainability standards in the Australian wooden furniture manufacturing sector. J Clean Prod 17:1594-1602

de Meijer M (2001) Review on the durability of exterior wood coatings with reduced VOC-content. Prog Org Coat 43:217-225

Dionco-Adetayo EA (2001) Utilization of wood wastes in Nigeria: a feasibility overview. Technovation 21:55-60

Dodoo A, Gustavsson L, Sathre R (2014a) Lifecycle carbon implications of conventional and low-energy multi-storey timber building systems. Energy Build 82:194-210

Dodoo A, Gustavsson L, Sathre R (2014b) Lifecycle primary energy analysis of low-energy timber building systems for multi-storey residential buildings. Energy Build 81:84-97

ERDC (2001) Aiming for sustainable product development furniture and building products. Energy Research and Development Corporation, Centre for Design at RMIT, Australia

Eshun JF, Potting J, Leemans R (2012) Wood waste minimization in the timber sector of Ghana: a systems approach to reduce environmental impact. J Clean Prod 26:67-78

EU (2006) Directive 2006/121/EC of the European Parliament and of the Council of 18 December 2006 amending Council Directive 67/548/EEC on the approximation of laws, regulations and administrative provisions relating to the classification, packaging and labelling of dangerous substances in order to adapt it to Regulation (EC) No 1907/2006 concerning the Registration, Evaluation, Authorisation and Restriction of Chemicals (REACH) and establishing a European Chemicals Agency

FAO (2001) Global forest resource assessment 2000. United Nations Food and Agriculture Organization (FAO), Rome

Field CB, Campbell JE, Lobell DB (2008) Biomass energy: the scale of the potential resource. Trends Ecol Evol 23:65-72

FIM (2017) Update on global timber demand. FIM Service Limited, Burford

Frihart CR, Birkeland MJ (2014) Soy properties and soy wood adhesives: soybased chemicals and materials. American Chemical Society, Washington D.C

Garcia CA, Hora G (2017) State-of-the-art of waste wood supply chain in Germany and selected European countries. Waste Manag 70:189-197

Gaussin M, Hu G, Abolghasem S, Basu S, Shankar M, Bidanda B (2013) Assessing the environmental footprint of manufactured products: a survey of current literature. Int J Prod Econ 146:515-523

George A (2008) Impact of carbon trading on wood products, forest and wood products. Australia, Forest and Wood Products Australia Limited

Gfeller B, Zanetti M, Properzi M, Pizzi A, Pichelin F, Lehmann M, Delmotte $L$ (2003) Wood bonding by vibrational welding. J Adhes Sci Tech 17:1573-1589

Goedkoop M, Heijungs R, Huijbregts M (2008) A life cycle impact assessment method which comprises harmonised category indicators at the midpoint and the endpoint level. Report l: characterisation. Den Haag, Impact world

Goreshnev M, Kazarin A, Lopatin V, Sekisov F, Smerdov O (2013) Combined timber drying method'. J Eng Phys Thermophys 86:336-339

Gunn JS, Ganz DJ, Keeton WS (2012) Biogenic vs. geologic carbon emissions and forest biomass energy production. GCB Bioenergy 4:239-242

Gurgel A, Reilly JM, Paltsev S (2007) Potential land use implications of a global biofuels industry. J Agric Food Ind Organ 5:2

Gustavsson L, Sathre R (2006) Variability in energy and carbon dioxide balances of wood and concrete building materials. Build Environ 41:940-951

Haque M, Langrish T (2005) Assessment of the actual performance of an industrial solar kiln for drying timber. Dry Technol 23:1541-1553
Harms-Ringdahl L, Jansson T, Malmén Y (2000) Safety, health and environment in small process plants—results from a European survey. I Saf Res $31: 71-80$

Hasan M, Langrish TA (2014) Numerical simulation of a solar kiln design for drying timber with different geographical and climatic conditions in Australia. Dry Technol 32:1632-1639

Havlík P, Schneider UA, Schmid E, Böttcher H, Fritz S, Skalský R, Aoki K, De Cara S, Kindermann G, Kraxner F, Leduc S (2011) Global land-use implications of first and second generation biofuel targets. Energy Policy 39:5690-5702

He Z (2017) Bio-based wood adhesives. CRC Press, Taylor and Francis Group, Boca Raton, p 366

Helwa N, Khater H, Enayet M, Hashish M (2004) Experimental evaluation of solar kiln for drying wood. Dry Technol 22:703-717

Hertwich EG, Pease WS, Koshland CP (1997) Evaluating the environmental impact of products and production processes: a comparison of six methods. Sci Total Environ 196:13-29

Hingston J, Collins C, Murphy R, Lester J (2001) Leaching of chromated copper arsenate wood preservatives: a review. Environ Pollut 111:53-66

Ibn-Mohammed T, Greenough R, Taylor S, Ozawa-Meida L, Acquaye A (2013) Operational vs. embodied emissions in buildings - a review of current trends. Energy Build 66:232-245

Ivanova G, Rolfe J (2011) Using input-output analysis to estimate the impact of a coal industry expansion on regional and local economies. Impact Assess Proj Apprais 29:277-288

Johansson L, Westerlund L (2000) An open absorption system installed at a sawmill: description of pilot plant used for timber and bio-fuel drying. Energy 25:1067-1079

Jones T, Kumar S (2007) Comparison of ergonomic risk assessments in a repetitive high-risk sawmill occupation: saw-filer. Int J Ind Ergon 37:744-753

Jones T, Kumar S (2010) Comparison of ergonomic risk assessment output in four sawmill jobs. Int J Occup Saf Ergon 16:105-111

Jurgensen M, Harvey A, Graham R, Page-Dumroese D, Tonn J, Larsen M, Jain T (1997) Review article: impacts of timber harvesting on soil organic matter, nitrogen, productivity, and health of inland northwest forests. Forest Sci 43:234-251

Klein D, Wolf C, Schulz C, Weber-Blaschke G (2016) Environmental impacts of various biomass supply chains for the provision of raw wood in Bavaria, Germany, with focus on climate change. Sci Total Environ 539:45-60

Kumar S, Kishankumar VS (2016) Thermal energy storage for a solar wood drying kiln: estimation of energy requirement. J Indian Acad Wood Sci 13:33-37

Laurent AB, Menard JF, Lesage P, Beauregard R (2016) Cradle-to-gate environmental life cycle assessment of the portfolio of an innovative forest products manufacturing unit. BioResources 11:8981-9001

LayThong H (1999) Rubberwood processing and utilization. Malayan forest records, 39th edn. Rubberwood processing and utilization, Malaysia

Le Quéré C, Raupach MR, Canadell JG, Marland G, Bopp L, Ciais P, Conway TJ, Doney SC, Feely RA, Foster P (2009) Trends in the sources and sinks of carbon dioxide. Nat Geosci 2:831-836

Lela B, Barišić M, Nižetić S (2016) Cardboard/sawdust briquettes as biomass fuel: physical-mechanical and thermal characteristics. Waste Manag 47:236-245

Lin L-D, Chen Y-F, Wang S-Y, Tsai M-J (2009) Leachability, metal corrosion, and termite resistance of wood treated with copper-based preservative. Int Biodeterior Biodegrad 63:533-538

Lindholm E-L, Berg S (2005) Energy requirement and environmental impact in timber transport. Scand J For Res 20:184-191

Lippke B, Wilson J, Perez-Garcia J, Bowyer J, Meil J (2004) CORRIM: life-cycle environmental performance of renewable building materials. For Prod J 54:8-19

Loxton EA, Schirmer J, Kanowski P (2013) Designing, implementing and monitoring social impact mitigation strategies: lessons from forest industry structural adjustment packages. Environ Impact Assess Rev 42:105-115

Mamatha BS, Sujatha D, Nath SK (2011) Soya based phenolic resins for plywood manufacture. J Indian Acad Wood Sci 8:112-116

Mansouri HR, Pizzi A, Leban J-M (2010) End-grain butt joints obtained by friction welding of high density eucalyptus wood. Wood Sci Technol 44:399-406 
Martins SA, Ganier T, Pizzi A, Del Menezzi CHS (2013) Parameter scanning for linear welding of Brazilian Eucalyptus benthamii wood. Eur J Wood Prod. 71:525-527

McDevitt JE, Grigsby WJ (2014) Life cycle assessment of bio-and petrochemical adhesives used in fiberboard production. J Polym Environ 22:537-544

Miles L, Kapos V (2008) Reducing greenhouse gas emissions from deforestation and forest degradation: global land-use implications. Science 320:454-455

Miner R (2010) Impact of the global forest industry on atmospheric greenhouse gases. Food and Agriculture Organization of the United Nations, Rome

Mirabella N, Castellani V, Sala S (2014) LCA for assessing environmental benefit of eco- design strategies and forest wood short supply chain: a furniture case study. Intl J Life Cycl Assess 19:1536-1550

Navarrete P, Pizzi A, Tapin-Lingua S, Benjelloun-Mlayah B, Pasch H, Rode K, Delmotte L, Rigolet S (2012) Low formaldehyde emitting biobased wood adhesives manufactured from mixtures of tannin and glyoxylated lignin. J Adhes Sci Technol 26:1667-1684

NCASI (2006) Energy and greenhouse gas impacts of substituting wood products for non-wood alternatives in residential construction in the United States, 925th edn. National Council for Air and Stream Improvement, Inc., Canada

Norgate TE, Jahanshahi S, Rankin WJ (2007) Assessing the environmental impact of metal production processes. J Clean Prod 15:838-848

Ong KS (1997) Comparison between drying of timber in a solar dryer and in an electrically-heated kiln. Dry technol 15:1231-1237

Päivinen R, Lindner M, Rosén K, Lexer M (2012) A concept for assessing sustainability impacts of forestry-wood chains. Eur J For Res 131:7-19

Phonetip K, Brodie G, Ozarska B, Belleville B (2017a) Drying Eucalyptus delegatensis timber by solar kiln using an intermittent drying schedule of conventional laboratory kiln. Dry. Technol 17:1-2

Phonetip K, Ozarska B, Belleville B, Brodie G (2017b). Using a conventional laboratory kiln as a simulation of solar cyclic drying. In: IUFRO division 5 conference/SWST 60th international convention forest sector innovations for a greener future. Vancouver, Canada

Phonetip K, Ozarska B, Brodie G, Belleville B, Boupha L (2018) Applying a GIS-based fuzzy method to identify suitable locations for solar kilns. BioResources. 13:2785-2799

Pizzi A (2006) Recent developments in eco-efficient bio-based adhesives for wood bonding: opportunities and issues. J Adhes Sci Technol 20:829-846

Pizzi A, Mittal KL (2011) Wood adhesives. CRC Press, Boston

Pizzi A, Leban J-M, Kanazawa F, Properzi M, Pichelin F (2004) Wood dowel bonding by high speed rotation welding. J Adhes Sci Technol 18:1263-1278

Poisson P, Chinniah Y (2016) Managing risks linked to machinery in sawmills by controlling hazardous energies: theory and practice in eight sawmills. Saf Sci 84:117-130

Puettmann ME, Wilson JB (2007) Life-cycle analysis of wood products: cradleto-gate $\mathrm{LCl}$ of residential wood building materials. Wood Fiber Sci 37:18-29

Ramasamy G, Ratnasingam J, Bakar ES, Halis R, Muttiah N (2015) Assessment of environmental emissions from sawmilling activity in Malaysia. BioResources 10:6643-6662

Ramesh T, Prakash R, Shukla K (2010) Life cycle energy analysis of buildings: an overview. Energy Build 42:1592-1600

Roy P, Nei D, Orikasa T, Xu Q, Okadome H, Nakamura N, Shiina T (2009) A review of life cycle assessment (LCA) on some food products. J Food Eng 90:1-10

Rus RM, Daud A, Musa KI, Naing L (2008) Knowledge, attitude and practice of sawmill workers towards noise-induced hearing loss in kota bharu, Kelantan. Malays J Med Sci 15:28

Sarkar A, Naha P, Nag J (1985) Development of suitable economic adhesives based on synthetic resin as well as proteinous materials and their application in the production of tea-chest plywood. IPIRTI research report No. 07
Schultz TP, Nicholas DD (2002) Development of environmentally-benign wood preservatives based on the combination of organic biocides with antioxidants and metal chelators. Phytochemistry 61:555-560

Sklar T (2008) Ethanol from wood waste an opportunity for refiners. Oil Gas J 106:54-59

Sommerhuber PF, Welling J, Krause A (2015) Substitution potentials of recycled HDPE and wood particles from post-consumer packaging waste in wood-plastic composites. Waste Manag. 46:76-85

Sreeja A, Edwin L (2013) Physical barriers: an alternative to prevent negative impacts of chemically treated wood. J Indian Acad Wood Sci 10:140-147

Suter F, Steubing B, Hellweg S (2017) Life cycle impacts and benefits of wood along the value chain: the case of Switzerland. J Ind Ecol 21:874-886

Taylor J (2003) Review of the environmental impact of wood compared with alternative products used in the production of furniture. Forest and Wood Products Research and Development Coorporation, Australia

Taylor J, Warnken M (2008) Wood recovery and recycling: a source book for Australia. Forest and Wood Products Research and Development Coorporation, Australia

Taylor J, Mann R, Reilly M, Warnken M, Pincic D, Death D (2005) Recycling and end-of-life disposal of timber products. Forest and Wood Products Research and Development Coorporation, Australia

Tilman D, Hill J, Lehman C (2006) Carbon-negative biofuels from low-input high-diversity grassland biomass. Science 314:1598-1600

Timmermann V, Dibdiakova J (2014) Greenhouse gas emissions from forestry in East Norway. Int J Life Cycle Assess 19:1593-1606

Tomasovic BS (2012) The fate of treated wood infrastructure. Va Environ Law J $30: 28$

Ugwu S, Ugwuishiwu B, Ekechukwu O, Njoku H, Ani A (2015) Design, construction, and evaluation of a mixed mode solar kiln with black-painted pebble bed for timber seasoning in a tropical setting. Renew Sustain Energy Rev 41:1404-1412

Van Hilst F, Hoefnagels R, Junginger M, Shen L, Wicke B (2017). Sustainable biomass for energy and materials: A greenhouse gas emission perspective. Working paper: Copernicus Institute of Sustainable Development, Utrecht, Utrecht University

Williamson TJ, Olweny M, Moosmayer V, Pullen SF, Bennetts H (2001) Environmentally friendly housing using timber-principles. Forest and Wood Products Research and Development Corporation, Austalia

Wilnhammer M, Lubenau C, Wittkopf S, Richter K, Weber-Blaschke G (2015) Effects of increased wood energy consumption on global warming potential, primary energy demand and particulate matter emissions on regional level based on the case study area Bavaria (Southeast Germany). Biomass Bioenergy 81:190-201

Wootton JT (2012) Effects of timber harvest on river food webs: physical, chemical and biological responses. PLoS ONE 7:43561

Ximenes FA, Gardner WD, Cowie AL (2008) The decomposition of wood products in landfills in Sydney, Australia. Waste Manag 28(11):2344-2354

Yang M, Rosentrater K (2015) Environmental effects and economic analysis of adhesives: a review of life cycle assessment (LCA) and techno-economic analysis (TEA) in 2015 ASABE Annual International Meeting, $\mathrm{p} 1$

Zanjani MK, Ait-Kadi D, Nourelfath M (2010) Robust production planning in a manufacturing environment with random yield: a case in sawmill production planning. Eur J Operational Res 201:882-891

Zhang W, Ma Y, Xu Y, Wang C, Chu F (2013) Lignocellulosic ethanol residuebased lignin-phenol-formaldehyde resin adhesive. Int J Adhes Adhes 40:11-18

Zomer RJ, Trabucco A, Bossio DA, Verchot LV (2008) Climate change mitigation: a spatial analysis of global land suitability for clean development mechanism afforestation and reforestation. Agric Ecosyst Environ $126: 67-80$

Zoolagud SS, Rangaraju TS, Narayana prasad TR, Mohandas KK (1997) Study on the suitability of deoiled soya bean flour and Jatropha seed cake flour as extenders for UF and PF resin adhesives for bonding MR and BWR grades of plywood. IPIRTI research report No. 97 